UDC 502.171

DOI https://doi.org/10.26661/hst-2019-1-78-07

\title{
SYSTEM ANALYSIS OF THE ECONOMY OF SUSTAINABLE DEVELOPMENT AS ENVIRONMENTALLY BALANCED AND SOCIALLY ORIENTED ONE
}

\author{
CVALENTYNA VORONKOVA \\ Engineering Institute of Zaporizhzhia National University (Zaporizhzhia, Ukraine) \\ E-mail: valentinavoronkova236@gmail.com, ORCID iD : 0000-0002-0719-1546 \\ Engineering Institute of Zaporizhzhia National University, Soborny Avenue, 226, \\ Zaporizhzhia, Ukraine, 69006 \\ (C) NATALYA METELENKO \\ Institute of Zaporizhzhia National University (Zaporizhzhia, Ukraine) \\ E-mail: natalia.metelenko@ gmail.com, ORCID ID: 0000-0002-6757-3124 \\ Engineering Institute of Zaporizhzhia National University, Soborny Avenue, 226, \\ Zaporizhzhia, Ukraine, 69006 \\ (C) VITALINA NIKITENKO \\ Institute of Zaporizhzhia National University (Zaporizhzhia, Ukraine) \\ E-mail: vitalina2006@ukr.net, ORCID iD: 0000-0001-9588-7836 \\ Engineering Institute of Zaporizhzhia National University, Soborny Avenue, 226, \\ Zaporizhzhia, Ukraine, 69006 \\ (C) IRYNA SILINA \\ Institute of Zaporizhzhia National University (Zaporizhzhia, Ukraine) \\ E-mail: ivsilina@ukr.net, ORCID ID 0000-0002-1205-0019 \\ Engineering Institute of Zaporizhzhia National University, Soborny Avenue, 226, \\ Zaporizhzhia, Ukraine, 69006
}

\begin{abstract}
The aim of the study is to improve the conceptual model of the systematic analysis of the sustainable development economy as an environmentally balanced and socially oriented one, which requires the construction of a model of this type of economy based on the introduction of information technologies and the expansion of digitalization. System analysis of the sustainable development economy as ecologically balanced and socially oriented is used in the article; the model of the economy of sustainable development is developed as an ecologically balanced and socially oriented one on the basis of the analysis of new problems related to digitalization; the directions of digitization of the sustainable development economy as ecologically balanced and socially oriented are substantiated. It is concluded that the conceptual model of system analysis of the economy in the age of digitalization is far-sighted, flexible and wise and does not undermine its supporting physical or social systems, but satisfies the needs of the population. Artificial intelligence and other technologies can improve the economy, create new types of work and promote human capabilities. In recent years, the digital revolution has transformed our lives through breakthrough technological ideas, turning over the century-old business model of companies, and creating an economy where algorithms dominate, leading to large-scale changes in work, business and economics. The conceptual model of the systematic analysis of sustainable development economy at the time of the digitalization is improved, which is based on studying problems and forecasting indicators of economy sustainability. The model of economic growth of the economy is developed - ecologically balanced and socially oriented, providing welfare for everyone. The
\end{abstract}

(C) Valentyna Voronkova \& Natalya Metelenko \& Vitalina Nikitenko \& Iryna Silina, 2019 
model consists of overcoming the set of problems of unemployment, growing property inequality and rapid climate change

Keywords: digitalization, welfare for everyone, economic growth of the economy, breakthrough technologies

\section{INTRODUCTION}

The urgency of the study of sustainable development as an ecologically balanced and sociallyoriented one is becoming increasingly important, as almost all governments have appealed to this topic, according to new reports from the Rome Club. Exiting beyond and declining later public welfare is a consequence of insufficient preparation of society for the future. From a systematic point of view, the sustainable development economy as an ecologically balanced and socially oriented has information, social and institutional mechanisms for controlling positive feedback cycles that cause an exponential increase in population and capital. In orderthe sustainable development economy to be ecologically balanced and socially oriented towards the ratio of people and the volume of capital has been regulated, it is necessary that the material standard of living is sufficient and guaranteed for all and fairly distributed.

The urgency of the research topic is that, firstly, modern societies have reached a certain level of well-being, have acquired scientific knowledge and technological capacity sufficient to secure financing and implementation of most of the transformations in terms of creating an economic development as environmentally balanced and socially oriented; secondly, the philosophical prerequisites for the emergence of the current state of the economy should be considered in order to cast doubt on the legitimacy of the ideals of material selfishness, which is currently a powerful driving force in the world and contribute to the elimination of the crisis of values, in order to promote the ideals of the New World Enlightenment 2.0;

Thirdly, the relevance of studying Anthropocene problems, in the context of which the economic wellbeing of humanity is separated from the destruction of natural processes, especially in agriculture, as well as from atmospheric pollution;

Fourth, the introduction of a balance between humanity and nature, in the short and long term, as well as between social and personal interests.

In order for the world to become material and energetic sustainable one, the physical resource flow in the economy must meet three conditions:

1) the speed of the use of renewable resources does not exceed the speed of their self-regeneration;

2) the rate of use of non-renewable resources does not exceed the rate of development of sustainable replacement substitutes for their replacement;

3) the rate of pollution does not exceed the assimilation capacity of the environment [1, p. 386].

At the beginning of the twentyfirst century, mental models are

System analysis of the economy of sustainable development as environmentally balnced and socially oriented one 
supported by terrible patterns of (chronic) poverty or rapid material growth, and by decisive action to support this growth at any price. Sustainable Development Economics should focus on qualitative development rather than on physical expansion. To move from a modern state to sustainability, the residual growth potential - an additional reserve of resources and pollutant emissions and those opportunities that are released by increasing the efficiency and changing the lives of many people - can be distributed among those who most need it.

The "stationary state" of the system can no longer continuously support the continuous development and improvement of the system. "Stable unemployment and rising inequality are two of the most pressing challenges faced by the richest countries in the world" [3, p.29].

The economy of sustainable development, as environmentally balanced and socially oriented, requires new rules, standards, borders, social agreements and restrictions on their establishment and protection; 3) for this type of economy as environmentally balanced it is necessary to minimize the use of nonrenewable resources and to prevent the depletion of renewable resources, using all resources with maximum efficiency. In the modern economy, the conditions are also rapidly changing: over the past decades, the digital revolution has transformed the media, entertainment, advertising, retail trade, changing each industry, every sphere of society, every profession [4, p.23].

The rapid development of the digital economy can worsen the situation with jobs, but with increasing growth, more and more companies are inclined to invest in automation and robotics, and the development of artificial intelligence (AI), called "robocalipsis".

\section{ANALYSIS OF LITERARY DATA AND RESOLVING THE PROBLEM}

The group of system dynamics at the Sloan School of Management from Massachusetts University of Technology from 1970 to 1972 formed a project that resulted in the limits of growth. In 2015, the document "Agenda 2030" [10] was adopted, the bulk of which consisted of 17 Sustainable Development Goals (SDG), as well as 169 targets for determining SDG. Among the SDGon the "Agenda 2020", SDG1-11 can be considered as socio-economic goals; SDG12 - responsible (steady) consumption and production, Objectives 13-15 - concern the protection of the environment, SDG16 - concerns peace, justice and institution building, and CSR 17 partnerships to achieve goals [10, p. 47-48].

The problematics of the use of the system dynamics and computer simulation theory to analyze the longterm causes and consequences of the CSR implementation, in particular the growth of the planet's population and the material economy, was highlighted by Donnelly Meadows, Dennis Meadows, Jorgen Randers, 
"Growth limits. 30 years later "[1], which forced us to think about the physical boundaries of human growth.

The authors note that everyone wants the growth, but it, like everything else, has its limits. Therefore, the main question is what can be done to create an environmentally balanced and socially-oriented economy which will bring welfare to everyone. In the report of the American Association for the Advancement of Science, the largest scientific association in the field of natural sciences in the world, in 2014, it was noted that most of the assumptions about natural disasters confirm the fundamental changes of our future.

Because of the greenhouse gas emissions, the air temperature will increase, which will gradually affect the rise of the world's oceans. However, geological studies show that in some cases, global climate change can be the result of minor changes.

In other words, if the air temperature reaches a certain limit, unpredictable and potentially irreversible changes can begin, which will have a large destructive effect noted by Naomi Klein in the paper "Capitalism against the climate". Environmentalists agree that climate change is already taking place, and according to verified data, 97 percent of experts in this field argue that human-induced changes have already begun, based not only on one study, but also on public statements in this area, which indicate about the threat of serious irreversible destruction [2].
In the work of Graham Maxton and Jorgen Randers "In search of prosperity. Managing Economic Developments to Reduce Unemployment, Irregularities and Climate Change "[3], one of the biggest challenges faced by the developed world today is the constant unemployment, growing inequality of property, and rapid climate change. Until now, most of the solutions to these problems have been politically unsustainable for the world, focused on short-term benefits and the desire for sustained economic growth.

Ordinary life changes in the eyes and we intuitively feel that the future will be completely different, and who knows what. Tim O'Reilly, who is called the oracle of the Silicon Valley, in the work of "WTF? What's the Future and Why It's Up to Us "[4] offers a glimpse into the world of innovators, breakthrough technologies, as well as understanding where modern (digital) technology will bring and what is the human's role in this world. Modern digital economy and decentralization conditions create the ecosystem of new services, workplaces, business models and industries; therefore, new values, skills, behavior patterns, terminology, ideas, expectations and aspirations of the era of informatization and digitalisation must be grasped.

Artificial intelligence and other technologies can improve the world, since they are powerful and diverse, but on the one hand, they create new kinds of labor, and on the other -

System analysis of the economy of sustainable development as environmentally balnced and socially oriented one 
people are waiting for loss of work and destabilization of the economy.

Brynjolfson E. and McAfee E. in the "Second Age of Machines: Work, Progress and Prosperity in the Time of Emergency Technologies" [6] believe that the exponential, digital and noncombinatorial powers have enabled for humankind two major one-time events in our history: the creation of a real, useful Artificial Intelligence (AI) and ensuring the communication of most people on the planet through a digital network.

Therefore, scientists believe that there is no better resource for improving the world and improving the condition of mankind than the world of 7.1 billion people, as the very mind can bring economic prosperity, and in the future, and computer well-being. Economist Julian Simon was one of the first who voiced this optimistic prediction that our minds are important in the economic sense and can lead to prosperity and economic growth.

Productivity growth is associated with innovations in technology and production methods, as digitization significantly changes the production economy. Mathis Vakerenagel and his colleagues measured the "ecological imprint" of mankind and compared it with the ecological capabilities of the planet, defining it as an area necessary for providing resources and absorbing emissions from the world community, concluding that human resources at that time exceeded the ecological potential of the planet by about 20 $\%$.According to these calculations, the last mankind was at a constant level in the 1980s, and now the output of the limit of this level is approximately $20 \%$ [1, p.19].

Thus, the authors conclude that in order to achieve sustainability, it is necessary to increase the consumption level in the poor countries of the world, while reducing the overall ecological imprint of humanity. The ecological footprint should not exceed the ecological potential of the planet. And although the economy (GDP) may continue to grow, the environmental footprint will not. Human extraction of natural resources, production of emissions and destruction of biodiversity should be reduced, and very sharply.

Environmental excretion is a situation where people use more resources than is currently restoring by nature, or more emissions than nature can absorb. The easiest way would be to stop destructive activities - to reduce the use of resources and harmful emissions, until they again fall below the sustainable environmental capabilities of the planet. However, history shows that it's not as easy as it might seem.

To do the mentioned, technological (digital) progress must be developed, human behavior must be changed, and a wider plan of horizons, as well as greater respect, care and exchange beyond the political boundaries, should be developed. That's exactly the way the country's future should be "programmed" purposefully and, moreover, on the principles of thrift, inclusiveness and balance. Such a holistic approach will benefit everyone - both society and the state, 
and international organizations, and future generations.

\section{PURPOSE AND OBJECTIVES OF THE STUDY}

The aim of the study is to improve the conceptual model of the systematic analysis of the sustainable development economy as an environmentally balanced and socially oriented one, which requires the construction of a model of this type of economy based on the introduction of information technologies and the expansion of digitalization.

To achieve the goal, the following tasks were set:

- to use the systematic analysis of the sustainable development economy as ecologically balanced and socially oriented;

- To develop a model of the sustainable development economy as an environmentally balanced and socially-oriented digitization;

- to substantiate the directions of digitization of the economy of sustainable development as ecologically balanced and socially oriented.

\section{CONCEPTUAL MODEL}

The concept of a sustainable development economy as an ecologically balanced and socially oriented based on a system analysis, which allows the formation of a new model of development about the state of the world and the trends in its development. We have improved the conceptual model of the systematic analysis of the sustainable development economy through digitalization, which is based on the modeling and forecasting of indicators of a sustainable economy by solving the problems faced by the rich countries of the world:

1. Period of robotization, which can increase unemployment and increase inequality.

2. Aging of the population, which is likely to increase public spending or increase inequality.

3. Increasingly more complex access to resources, which may change the traditional pattern of consumption.

4. Climate change, which will require more climate change and more government spending.

5. Low productivity growth in those sectors of the economy, where most people will be employed, namely, unemployed services, cultural sphere and care services, which will reduce the growth of potential consumption [3, p.143].

If we approach these difficulties from the standpoint of the ideology of an overly free market, then higher levels of unemployment and social inequality can be obtained.

The model of economic growth of the economy - an ecologically balanced and socially-oriented system approach - has to provide "welfare for all". We have analyzed that the model consists of overcoming the set of problems of unemployment, growing property inequality and rapid climate change.

The model is a simplified representation of reality.

In order to solve the actual problems of achieving a socially

System analysis of the economy of sustainable development as environmentally balnced and socially oriented one 
oriented economy, it is necessary from the point of view of the systemic approach:

1) to eliminate poverty;

2) to overcome unemployment;

3) to try to satisfy the real needs of self-affirmation, public recognition, self-realization;

4) to promote the recognition of personality as the ultimate goal of human effort;

5) contribute to the achievement of equilibrium by addressing the abovementioned problems.

"The age of growth gives way to a century of equilibrium. Achievement of this equilibrium is a task of the next several centuries "[1, p. 398].

To do this, we need to destroy the ideology of market fundamentalism, which is the greatest enemy of our planet, and spur the new ideology of sustainable development, based on the fight against air pollutants and greenhouse gases. As an example, when China became a "world studio", it also became the largest on the planet "chimney".

One of the causes of the climate crisis is the globalization model [2, p.84], which is based on logic that allows employers to exploit workers for a penny, while not prohibiting them from burning a huge amount of coal without spending much on environmental protection. Cheap labor is in a heap, as it turned out, with the terrible exploitation of the planet [9].

Climate problems are an inevitable consequence of the uncontrollability of Western societies. Unfortunately, the ecological imprint of humanity continues to grow despite the progress in technology and institutions. This is becoming a more and more serious problem, since humanity is already in a state of instability and it is necessary to return the environmental footprint to a level that does not exceed the long-term ecological potential of the planet, which will take a long time.

Anthropogenic changes in the planet are currently extremely serious: today perfluorooctanoic acid is found in the tissues of polar bears and all humans on the earth;

In the digestive system, $90 \%$ of seabirds are found in plastic, and the microparticles resulting from the annual decomposition of millions of tons of plastic waste today are present everywhere;

$90 \%$ of the total amount of oil consumed by mankind dates from 1958 , with $50 \%$ of them - for the period since 1984, and it has forever guaranteed the presence of technical carbon in the ice crisis; mass losses of bio-diversity diversity are no less catastrophic;

Threats and soil degradation, drought and the spread of invasive species can exacerbate the danger that threatens future generations [10, $\mathrm{p}$. 89]

Humanity is still guided by the short-term goals of increasing consumption, employment growth and financial security - up to the tragic finale, ignoring the clear and powerful signals that are gaining, which should be stopped by developing the concept of sustainable economic development as environmentally balanced and socially oriented. We have lost too much time due to the weak environmental policy, so now we need to reduce the volume of harmful 
emissions that threatens the aggressive logic that underlies the modern economic system.

In addition, technology-driven performance, which today is termed breakthrough, is usually creeping into the world imperceptibly. People need time to figure out how to use the best of the new technology, and the industries to modernize their plants and production methods. Let's take an example: electrification began in the 1890 s, but it took forty years before economists saw the rise in productivity that everyone was waiting for. The revolution in personal computers also occurred with the effect of delay, and the rapid growth of productivity began in the 1990's.

Economic growth in the era of digitalization depends on the available technology, whether well-funded and human capital of the country is adapted to their use. Information technology has already begun demonetization. Tasks performed by employees -programs, reflect the scheme of the digital organization. Today, technology is a means to solve problems, to create an added reality that will make it impossible for people to carry out.

\section{CONCLUSIONS}

The model of economic growth of the economy is developed ecologically balanced and sociallyoriented, which provides welfare for all, and the return of the ecological imprint to a level that does not exceed the long-term ecological potential of the planet. An urgent action plan is required from government officials of each level to the desire to resist polluters who can bring danger.

The authors of the Rome Club believe that it takes another decade before the effects of the outbreak become clearly visible, and two decades before the fact of crossing the boundaries will be universally recognized. The proposed model challenges the long-standing concepts of the free market economy and explains how to reduce unemployment, inequality and speed of climate change, continuing economic growth, raising the welfare of citizens and caring for the future.

The current concept will allow, on the one hand, to build a model of sustainable development, and on the other hand, to adjust the parameters of the development of the system in accordance with the conditions of digitalization, since the existing economic system has put the developed world on a running track that directs the society in a hopeless social and ecological direction. In order to function, the modern economic system requires greater use of environmental and information resources.

The development of data storage technologies and the growth of computing power - a process that mutually supports each other. The more information is accumulated, the larger will be the investment in powerful computers and large repositories, where data will be gathered for further processing and analysis needed to make business management decisions. The more

System analysis of the economy of sustainable development as environmentally balnced and socially oriented one 
powerful the computers will be, the easier it will be to gather a large array of information and get a more comprehensive and in-depth analysis.

The developed economic growth model, ecologically balanced and socially oriented, shows that current trends on the Earth have no signs of sustainability, and traditional responses to these problems usually depend on the type of economic growth that is firmly linked to the additional consumption of resources. Combined with the continued growth of the population, it is further depriving today's trend of sustainability. The inevitable result of this process is local and global ecological collapse, which completely eliminate the goals of sustainable development (SDG).

Current urgent needs are inevitable: we need to develop new types of human goals, and, if possible, a new social enlightenment, a new model of the concept of economic growth as environmentally balanced and socially oriented. However, our civilization needs the New Enlightenment Era to overcome the problems of "complete peace". "Full world" needs the equivalent of the "New Enlightenment Era" and emphasizes the need for a fair transition through a systematic approach.

The world is approaching the inevitable social transformation on the path to global sustainability. The only chance for the prosperity of mankind in the twenty-first century is within the planet or, in other words, in a safe functional space of the planetary boundaries.
The concept of an environmentally balanced and socially-oriented economy attaches great importance to "benign" investment, the "in-depth choice of reforms" of the developing country towards the creation of an environmentally "clean society".

The developed economic growth model, ecologically balanced and socially oriented, is a modern study of the necessity, possibilities and benefits of a global transition to sustainable development, in order to emphasize the need to act immediately to become a path to the future, where everybody will live in prosperity and equilibrium.

The idea of the "New Enlightenment Era" is about to establish a balance. For Eastern cultures, its strength is better known than the capitalist and colonial countries of the West.

The concept of the Tew Enlightenment, which underlies the model of economic growth of the economy - ecologically balanced and socially-oriented, meets the conditions of Anthropogen.

"New Enlightenment Era" is not only necessary but also possible, which will lead us beyond the limits of materialism, reductionism and selfishness. We must transform all major sectors of the economy in order not to go beyond the planetary boundaries. This will require a systematic approach and rethinking priorities in the long run.

Our dominant values need to be expanded and called for the "New Enlightenment", the ideals of which are laid down in the model of economic growth of the economy - 
ecologically balanced and socially oriented.

At the core of the developed model of economic growth of the economy - ecologically balanced and socially oriented - the creation of a world where the development and application of technologies show their plasticity, takes into account climate change, respecting biological diversity; a world in which humanity lives in harmony with nature and in which wildlife and other biological species are protected.

Of course, it takes into account the need for urgent measures to combat climate change (Goal 13);

the importance of preserving and moderately using oceans, seas and marine resources within sustainable development (Goal 14);

protection, reproduction and promotion of the sustainable use of land ecosystems, sustainable forest management, combating environmental degradation, halting land degradation and rehabilitation, and halting the loss of biodiversity (Target 15).

However, a compromise between the socioeconomic and environmental CDG needs to be introduced so that the problem of socioeconomic deficit does not lead to the consistent destruction of the environment. These goals should apply to all people on Earth - 7.6 billion, 9 billion less than in 20 years and maybe 11.2 billion more by the end of the century.

\section{REFERENCES}

1. Medouz D., Medouz D., Randers Y. (2018). Mezhi zrostannia. 30 rokiv potomu. Kyiv: Pabulum. 8-9.

2. Klein N. (2016). Змінюється все. Капіталізм проти клімату / Пер. $з$ англ. Дмитра Кожедуба. К.: Наш формат. 11.

3. Maxton J., Randers Y. (2017). У пошуках добробуту. Керування економічним розвиткам для зменшення безробіття, нерівності та змін клімату. Київ: Пабулум. 320.

4. O' Rajli Tim (2018). Hto znaye, yakim bude majbutnye / Per. z angl. Yuliya Kuzmenko. K. Nash format.448.

5. Ross A. (2017). The industries of the future / Per. z angl. Yuliya Kuzmenko. K.: Nash format. 55-90.

6. Brynjolfsson E., McAfee E. (2016). The Second Machine Age: Work, Progress and Prosperity in a Time of Brilliant Technologies. Kyiv: FUND. 78-86.

7. Christopher S. (2018). Total automation. How computer algorithms change life. Kyiv: Our format. 280. 296.

8. Chang H.-J. (2018). 23 things they don't tell you about capitalism. Kyiv: Nash format.

9. Dyson G. (2012). Turing's Cathedral. New York: Pantheon. 230-239.

10. Vaytszeker E. U. fon, Viykman A. (2019). Come On! Kapitalizm, nedalekohlyadnist, naselennya i ruynuvannya planety. Dopovid Rymskomu kulubu. Per. z anhl. YU.Sirosh; za nauk. red. V.Vovka, V.Butka. K.: Samit-Knyna.276.

Воронкова, В. Г. - доктор філософських наук, професор, завідувач кафедри менеджменту організацій та управління проектами, Інженерний інститут Запорзького національного університету (Запоріжжя, Україна)

E-mail: valentinavoronkova236@gmail.com, ORCID iD : 0000-0002-0719-1546

System analysis of the economy of sustainable development as environmentally balnced and socially oriented one 
Метеленко, Н. Г. - доктор економічних наук, професор, завідувач кафедри фінансів, банківської справи та страхування, академік АЕНУ, Інженерний інститут Запорізького національного університету (Запоріжжя, Україна)

E-mail: natalia.metelenko@gmail.com, ORCID ID 0000-0002-6757-3124

Нікітенко, В. О. - кандидат філософських наук, доцент, доцент кафедри менджменту організацій та управління проектами, Інженерний інститут Запорізького національного університету (Запоріжжя, Україна)

E-mail: vitalina2006@ukr.net, ORCID iD: 0000-0001-9588-7836

Сіліна, I. В. - кандидат економічних наук, доцент, доцент кафедри фінансів, банківської справи та страхування, Інженерний інститут Запорізького національного університету (Запоріжжя, Україна)

E-mail: ivsilina@ukr.net, ORCID ID 0000-0002-1205-0019

\section{СИСТЕМНИЙ АНАЛІЗ ЕКОНОМІКИ СТАЛОГО РОЗВИТКУ ЯК ЕКОЛОГІЧНО ЗБАЛАНСОВАНОЇ І СОЦАЛЬНО-ОРІЄНТОВАНОЇ}

Анотація. Метою дослідження є вдосконалення концептуальної моделі системного аналізу економіки сталого розвитку як екологічно збалансованої i соціальноорієнтованої, що вимагає побудови моделі економіки такого типу, що базується на упровадженні інформаційних технологій та розширення діджиталізації (цифровізації). Використано системний аналіз економіки сталого розвитку як екологічно збалансованої та соціально-орієнтованої; розроблено модель економіки сталого розвитку як екологічно збалансованої та соціально-орієнтованої на основі аналізу нових проблем, що пов'язані 3 діджиталізацією; обгрунтовано напрями діджиталізації (цифровізації) економіки сталого розвитку як екологічно збалансованої і соціально-орієнтованої. Зроблено висновок, що концептуальна модель системного аналізу економіки за доби діджиталізації є далекоглядною, гнучкою і мудрою і не підриває свої підтримуючі фізичні або соціальні системи, а задовольняє потреби населення. Штучний інтелект та інші технології можуть покращити економіку, створити нові види праці та сприяти розширенню людських можливостей. Протягом останніх років цифрова революція (діджиталізація) трансформувала наше життя шляхом проривних технологічних ідей, перевернувши столітню бізнес-модель компаній, та створивши економіку, де владарюють алгоритми, які привели до масштабних змін у роботі, бізнесі й економіці. Вдосконалено концептуальну модель системного аналізу економіки сталого розвитку за доби діджиталізації, в основі якої вивчення проблем та прогнозування показників сталості економіки. Розроблена модель економічного зростання економіки - екологічно збалансованої і соціально-орієнтованої, що забезпечує добробут для всіх. Модель складається з подолання множини проблем безробіття, зростаючої майнової нерівності та стрімких змін клімату

Ключові слова: діджиталізація, добробут для всіх, економічне зростання економіки, проривні технології.

Воронкова, В. Г. - доктор философских наук, профессор, заведующая кафедрой менеджмента организаций и управления проектами, Инженерный институт Запорожского национального университета (Запорожье, Украина)

E-mail: valentinavoronkova236@gmail.com, ORCID iD : 0000-0002-0719-1546

Метеленко, Н. Г. - доктор экономических наук, прфессор, заведующая кафедрой финансов, банковского дела и страхования, академик АЭНУ, Инженерный институт Запорожского национального университета (Запорожье, Украина)

E-mail: natalia.metelenko@gmail.com, ORCID ID 0000-0002-6757-3124

(C) Valentyna Voronkova \& Natalya Metelenko \& Vitalina Nikitenko \& Iryna Silina, 2019 
Никитенко, В. А. - кандидат философских наук, доцент, доцент кафедры менеджмента организаций и управления проектами, Инженерный институт Запорожского национального университета (Запорожье, Украина)

E-mail: vitalina2006@ukr.net, ORCID iD : 0000-0001-9588-7836

Силина, И. В. - кандидат экономических наук, доцент, доцент кафедры финансов, банковского дела и страхования, Инженерный институт Запорожского национального университета (Запорожье, Украина)

E-mail: ivsilina@ukr.net, ORCID ID 0000-0002-1205-0019

\section{СИСТЕМНЫЙ АНАЛИЗ ЭКОНОМИКИ УСТОЙЧИВОГО РАЗВИТИЯ КАК ЭКОЛОГИЧЕСКИ СБАЛАНСИРОВАННОЙ И СОЦИАЛЬНО-ОИЕНТИРОВАННОЙ}

Аннотация. Целью исследования есть усовершенствование концептуальной модели системного анализа экономики устойчивого развития как экологически сбалансированной и социально-ориентированной, что требует построения модели экономики такого типа, которая базируется на внедрении информационных технологий и расширения диджитализации (цифровизации). Использован системный анализ экономики устойчивого развития как экологически сбалансированной и социальноориентированной, разработана модель экономики устойчивого развития как экологически сбалансированной и социально-ориентированной на основе анализа новых проблем, которые связаны с диджитализацией; обоснованы направления диджитализации (цифровизации) экономики устойчивого развития как экологически сбалансированной и социально-ориентированной. Сделан взвод, что концептуальная модель системного анализа экономики эпохи диджитализации есть дальновидной, гибкой и мудрой и не подрывает поддерживающие физические и социальные системы, a удовлетворяет потребности населения. Искусственный интеллект и другие технологии могут улучить экономику, создать нвые виды труда и содействовать расширению человеческих возможностей. На протяжении последних лет цифровая революция (диджитализация) трансформировала нашу жизнь путем прорывных технологических идей, трансформировав столетнюю бизнес-модель компаний, и создвав экономику, где господствуют алгоритмы, которые привели к масштабным изменениям в работе, бизнесе и экономике. Усовершенствована концептуальная модель системного анализа экономики устойчивого развития в условиях диджитализации, в основе которой изучение проблем и прогнозирование показателей устойчивости экономики. Разработана модель экономического увеличения экономики - экологически сбалансированной и социально-ориентированной, которая обеспечивает благосостояние для всех. Модель состоит с преодоления проблем безработицы, увеличивающегося имущественного неравенства и стремительных изменений климата.

Ключевые слова: дидджитализация, благосостояние для всех, экономический рост экономики, прорывные технологии.

Received date 02.09.2019

Accepted date 15.10.2019

Published date 15.11.2019

System analysis of the economy of sustainable development as environmentally balnced and socially oriented one 